Case Report

\title{
Invasive Mucormycosis Induced Pneumopericardium: A Rare Cause of Pneumopericardium in an Immunocompromised Patient
}

\author{
Sana Khan, ${ }^{1}$ Muhammad Waqar Elahi, ${ }^{2}$ Waqas Ullah, \\ Hafez Mohammad Ammar Abdullah, ${ }^{2}$ Ejaz Ahmad, ${ }^{3}$ \\ Mayar Al Mohajer, ${ }^{4}$ and Aneela Majeed ${ }^{4}$ \\ ${ }^{1}$ Griffin Hospital, Ansonia, CT 06401, USA \\ ${ }^{2}$ Khyber Teaching Hospital, Peshawar 25000, Pakistan \\ ${ }^{3}$ Nishtar Hospital, Multan 60000, Pakistan \\ ${ }^{4}$ University of Arizona, Tucson, AZ 85701, USA \\ Correspondence should be addressed to Hafez Mohammad Ammar Abdullah; dr.ammarabdullah@gmail.com
}

Received 15 February 2017; Accepted 30 April 2017; Published 17 May 2017

Academic Editor: Tomoyuki Shibata

Copyright (C) 2017 Sana Khan et al. This is an open access article distributed under the Creative Commons Attribution License, which permits unrestricted use, distribution, and reproduction in any medium, provided the original work is properly cited.

\begin{abstract}
Mucor and Rhizopus cause life-threatening infections primarily involving the lungs and sinuses, which disseminate very rapidly by necrosis and infarction of the contiguous tissues. We present a case of a 64-year-old African American posttransplant patient who presented with a productive cough and weight loss. He had a past surgical history of renal transplant for renal cell carcinoma and was on dual immunosuppressive therapy, that is, mycophenolate and tacrolimus. During his hospital stay, he developed a pneumopericardium due to the direct extension of a lung lesion. The diagnosis was made by radiological imaging and PCR result which was consistent with Mucor species. He was treated with antifungal therapy. The purpose of this report is to highlight the unusual association of mucormycosis with pneumopericardium.
\end{abstract}

\section{Introduction}

Mucormycosis is caused by a filamentous fungus which belongs to the subphylum mucoromycotina. Diabetics and immunocompromised patients are at a higher risk to acquire the infection but a few cases have been reported in immunocompetent patients with severe soft tissue trauma. It is acquired by inhalation of environmental spores (sporangiospores). Clinical presentation of this disease varies depending upon the involvement of the organ and immune status of the patient. The most common manifestations are rhinocerebral and pulmonary but other manifestations include cutaneous, gastrointestinal, and disseminated infections $[1,2]$. A high index of suspicion is essential because the signs and symptoms and the radiological findings are very nonspecific.
Diagnosis is usually made by histopathological documentation of ribbon-like hyphae in tissue. Some researchers suggest PCR for a rapid diagnosis to save time $[2,3]$. Successful therapy involves early diagnosis, surgical debridement of the infected tissues, high dose systemic antifungal therapy (IV amphotericin B), and reversal of predisposing factors $[3,4]$. Untreated cases of mucormycosis have devastating complications. In DKA patients, high activity of ketone reductase enzyme in the acidic and hyperglycemic environment leads to systemic dissemination of the infection [4, 5]. Similarly, in immunocompromised and organ transplant patients, infection from the lungs can spread contiguously to the skin and mediastinum or homogeneously to distant organs. Very rarely the lung infection can spread to the pericardium. 


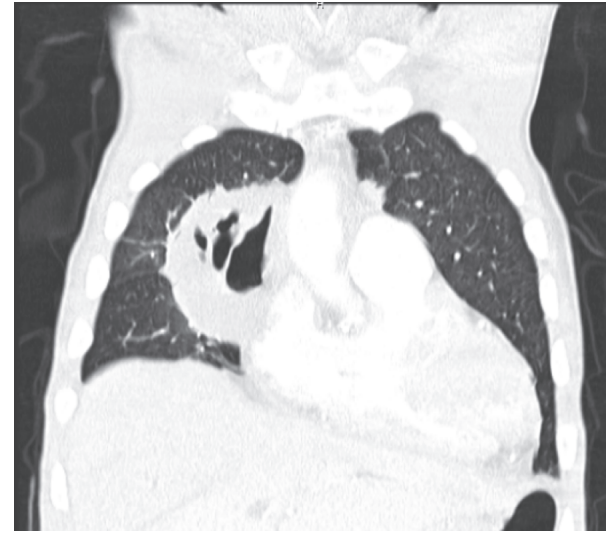

FIGURE 1: CT of the chest revealing a large right middle lobe cavitary mass $\left(6.5 * 7.6 * 8.1 \mathrm{~cm}^{3}\right)$ with bilateral pulmonary nodules and a small pericardial effusion.

\section{Case Presentation}

A 64-year-old African American male patient presented with a two-week history of a productive cough associated with low-grade fever, worsening dyspnea, generalized weakness, and an unintentional weight loss of $20 \mathrm{lbs}$ over the previous 3 months. He had a past history of bilateral nephrectomy for renal cell carcinoma and had deceased donor renal transplant for end-stage kidney disease three months prior to presentation. He was on hemodialysis for almost 10 years prior to renal transplantation. The patient was on maintenance immunosuppression consisting of mycophenolate mofetil, tacrolimus, and corticosteroids along with trimethoprim/sulfamethoxazole and valganciclovir for microbial prophylaxis. His comorbidities included diabetes mellitus, hypertension, COPD, and chronic rate-controlled atrial fibrillation. He denied any ill contact, travel history, night sweats, hemoptysis, or altered bowel habits.

On examination, he had stable vital signs except for lowgrade fever. His chest examination revealed decreased breath sounds in the right upper zone, bilateral basal crackles, and a prominent pericardial rub. Lung examination revealed dull percussion notes in the lower lobes bilaterally. Laboratory data showed a low hemoglobin level of $8.2 \mathrm{~g} / \mathrm{dL}$ with a mean corpuscular volume of $69 \mathrm{fL} /$ red cell, a leukocytosis of $16,700 / \mu \mathrm{L}$, and a platelet count of $544,000 / \mu \mathrm{L}$. His renal function tests were normal with a serum creatinine level of $0.79 \mathrm{mg} / \mathrm{dL}$ and blood urea nitrogen of $19 \mathrm{mg} / \mathrm{dL}$. He had normal serum electrolyte levels. His fasting serum glucose level was $163 \mathrm{mg} / \mathrm{dL}$. CT of the chest was done which showed a large right middle lobe cavitary mass $\left(6.5 * 7.6 * 8.1 \mathrm{~cm}^{3}\right)$ with bilateral pulmonary nodules and a small pericardial effusion (Figure 1).

Blood and sputum cultures were obtained and the patient was initiated on vancomycin and meropenem. Mycophenolate, tacrolimus, and prednisone were held on admission. His white cell count continued to remain elevated and it was decided to biopsy the lung cavitary mass. An ultrasound guided core needle biopsy was attempted but the patient

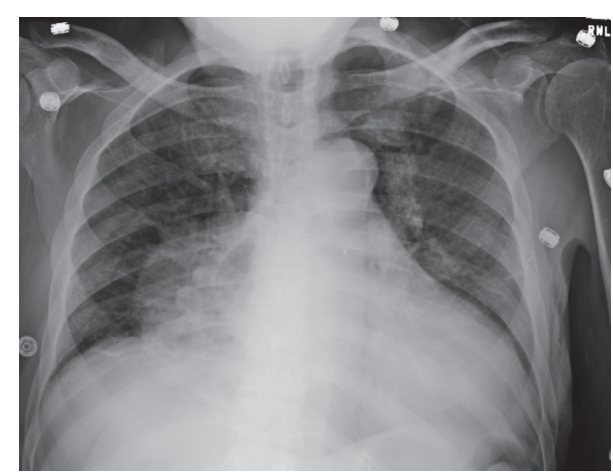

FIGURE 2: Chest X-ray showing a pneumopericardium, most probably due to the direct extension of the fungal infection (day 15).

desaturated during the first attempt. He was transferred to intensive care unit due to acute respiratory distress and required mechanical ventilation. After he became hemodynamically stable, a needle biopsy was successfully reattempted. Biopsy report of the lung tissue revealed necrotic lung parenchyma with broad aseptate ribbon-like hyphae consistent with Mucor species. The hyphae were identified on hematoxylin and eosin stain and confirmed with Periodic Acid-Schiff(PAS) and Grocott-Gomori's Silver (GMS) special stains. Mucicarmine special stain was negative. Biopsy of the lung tissue was negative for malignant cells. A PCR analysis of histologic specimen was positive for mucormycosis; however, the fungal cultures remained negative. Amphotericin B (lipid formulation) was initiated. Blood cultures were also positive for vancomycin-resistant enterococci (VRE), so daptomycin was started and vancomycin and meropenem were discontinued.

Despite antifungal and antibiotic treatment, the respiratory status of the patient did not improve and he had to be reintubated on hospital day 8 . The following day, the patient became hypotensive with a blood pressure of $80 / 60 \mathrm{mmHg}$ and a heart rate of 110 beats/min. He also developed acute kidney injury with a creatinine of $1.6 \mathrm{mg} / \mathrm{dL}$ and anuria of $200 \mathrm{~mL}$ over 24 hours. Amphotericin B was switched to isavuconazonium sulfate, due to his rising creatinine levels.

On hospital day 15 , chest $\mathrm{X}$-ray revealed air in the pericardial sac, that is, pneumopericardium, consistent with a direct extension of the known cavitary fungal pneumonia in the chest through the mediastinum into the pericardium (Figure 2). Two days later a repeat chest X-ray suggested a new patchy right lower lobe opacity consistent with pneumonia and persistent pneumopericardium (Figure 3). Despite maximal vasopressor and mechanical ventilatory support, the patient expired on hospital day 22.

\section{Discussion}

Pneumopericardium is a collection of gas in the pericardial cavity. It is most commonly caused by direct trauma to the pericardial layer surrounding the heart or due to the aggressive resuscitation of preterm neonates with positive pressure ventilation $[5,15,16]$. Other causes include stomach 
TABLE 1: Characteristic findings of previously reported cases of fungal pneumopericardium.

\begin{tabular}{|c|c|c|c|c|c|c|c|}
\hline Case number & Author & Age/sex & $\begin{array}{l}\text { Underlying } \\
\text { condition }\end{array}$ & Primary disease & Organism & Treatment & Outcome \\
\hline 1 & $\begin{array}{c}\text { Rosenbaum et al. } \\
{[6]}\end{array}$ & $41 / \mathrm{M}$ & N/A & $\begin{array}{l}\text { Mycotic aortic } \\
\text { aneurysm }\end{array}$ & $\begin{array}{c}\text { Histoplasma } \\
\text { capsulatum }\end{array}$ & $\mathrm{N} / \mathrm{A}$ & Died \\
\hline 2 & Xie et al. [7] & $51 / \mathrm{M}$ & $\begin{array}{c}\text { Invasive } \\
\text { pulmonary } \\
\text { aspergilloma }\end{array}$ & $\begin{array}{l}\text { Aspergillus } \\
\text { empyema }\end{array}$ & Aspergillus & $\begin{array}{l}\text { Irrigation and } \\
\text { debridement } \\
\text { of empyema }\end{array}$ & Recovered \\
\hline 3 & van Ede et al. [8] & $29 / \mathrm{M}$ & $\begin{array}{c}\text { Acute } \\
\text { myelogenous } \\
\text { leukemia }\end{array}$ & $\begin{array}{c}\text { Pulmonary invasive } \\
\text { aspergillosis }\end{array}$ & Aspergillus & $\begin{array}{c}\text { Amphotericin } \\
\text { B }\end{array}$ & Died \\
\hline 4 & Müller et al. [9] & $40 / \mathrm{M}$ & $\begin{array}{c}\text { Chronic } \\
\text { myelogenous } \\
\text { leukemia }\end{array}$ & $\begin{array}{l}\text { Progressive dyspnea, } \\
\text { lungs consolidation }\end{array}$ & Aspergillus & $\begin{array}{c}\text { Amphotericin } \\
\text { B }\end{array}$ & Died \\
\hline 5 & Owens et al. [10] & $14 / \mathrm{M}$ & $\begin{array}{c}\text { Acute } \\
\text { lymphoblastic } \\
\text { leukemia }\end{array}$ & Pulmonary nodules & Aspergillus & $\begin{array}{c}\text { Amphotericin } \\
\text { B }\end{array}$ & Recovered \\
\hline 6 & Yilmaz et al. [11] & $59 / \mathrm{F}$ & $\begin{array}{c}\text { Acute } \\
\text { lymphoblastic } \\
\text { leukemia }\end{array}$ & $\begin{array}{c}\text { Invasive pulmonary } \\
\text { aspergillosis }\end{array}$ & Aspergillus & $\begin{array}{c}\text { Amphotericin } \\
\text { B }\end{array}$ & Recovered \\
\hline 7 & $\begin{array}{l}\text { Serrano-Gonzalez } \\
\text { et al. [12] }\end{array}$ & $5 / \mathrm{M}$ & $\begin{array}{c}\text { Acute } \\
\text { lymphoblastic } \\
\text { leukemia }\end{array}$ & $\begin{array}{c}\text { Invasive pulmonary } \\
\text { aspergillosis }\end{array}$ & Aspergillus & $\begin{array}{l}\text { Amphotericin } \\
\mathrm{B} \text {, itraconazole }\end{array}$ & Recovered \\
\hline 8 & $\begin{array}{l}\text { Bhindi and Rees } \\
\text { [13] }\end{array}$ & $92 / \mathrm{M}$ & $\begin{array}{l}\text { Large cell } \\
\text { esophageal } \\
\text { lymphoma }\end{array}$ & Pneumopericardium & $\begin{array}{l}\text { Candida } \\
\text { albicans }\end{array}$ & Fluconazole & Recovered \\
\hline 9 & Li et al. [14] & $60 / \mathrm{M}$ & N/A & Pericarditis & $\begin{array}{c}\text { Candida } \\
\text { glabrata, } K . \\
\text { pneumo- } \\
\text { niae, strep. } \\
\text { viridans }\end{array}$ & $\begin{array}{l}\text { Antimycotics, } \\
\text { antibiotics }\end{array}$ & Recovered \\
\hline
\end{tabular}

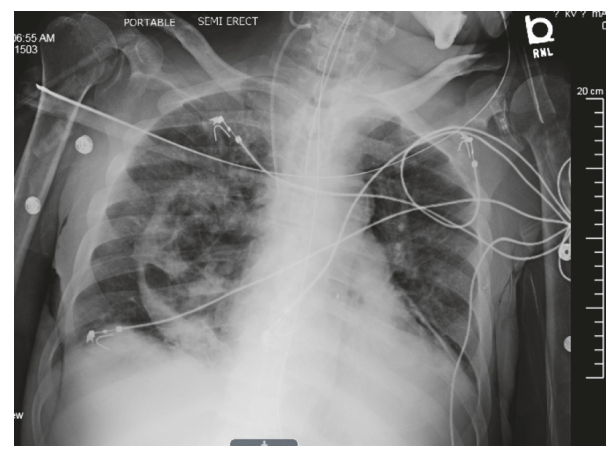

FIGURE 3: Chest X-ray showing a new patchy right lower lobe opacity consistent with pneumonia and persistent pneumopericardium (day 17).

or liver fistula, lung inflammations, and pericarditis by gas forming bacteria like clostridium [17]. Infections most commonly associated with pneumopericardium are mycobacterium tuberculosis; however, there have been a few reports of fungal infections [6].

Review of the literature showed that more than $50 \%$ of fungal pneumopericardium is caused by aspergillus. There have been reports of Candida and Histoplasma causing pneumopericardium too [6-14]. However, there have been no previous reports of mucormycosis causing pneumopericardium. Most of these patients were immunocompromised; however, most of the cases had lung infections as the primary focus. With appropriate treatment, many of these patients had a successful recovery with the exception of two patients who expired. The characteristic findings of these cases are given in Table 1.

Fungal pneumopericardium occurs mostly due to direct invasion of the pericardial sac by the fungal hyphae, which can additionally lead to hemoptysis as well. Damage to the alveolar walls due to any cause allows air to travel to the lung hilum and mediastinum and all the way to the pericardial cavity $[5,15]$. Symptomatic patients present with precordial pain, hypotension, pulsus paradoxus, shortness of breath, and cyanosis occasionally $[5,15,18]$. On auscultation, a characteristic murmur caused by the heart movement against the air or a loud metallic sound is heard $[5,18]$. Depending on the amount of gas in the pericardial cavity, patients can have muffled, distant, or absent heart sounds $[5,16,18]$. In some cases, shifting precordial tympany can be felt on percussion $[5,18]$.

Laboratory investigations like EKG and radiological imaging can aid in the diagnosis. EKG can be normal or show low voltage QRS complexes and ST segment elevations in associated tamponade and pericarditis, respectively $[5,15]$. Chest X-ray and echocardiography are both diagnostic for pneumopericardium $[5,18]$. Chest X-ray in 
the posteroanterior view does not distinguish pneumopericardium from pneumomediastinum. However, in pneumopericardium, serial chest X-rays in left lateral decubitus position show air movement in the pericardial sac between two films while the air column remains stable in pneumomediastinum $[5,15]$. Similarly, pneumopericardium has an air column below the level of the aortic arch, forming a halo sign in the pericardial cavity while pneumomediastinum forms a triangular air sign behind the sternum $[15,19]$. The cardiac shadow appears larger in usual pneumopericardium while it appears to be smaller in tension pneumopericardium $[15,20]$. Echocardiography complements chest X-ray findings by demonstrating air around the heart and also shows any pericardial fluid if present; however, the air in the pericardial cavity does interfere with the assessment of cardiac activity [20].

Other useful tests include a CT chest, which provides details of the air column around the heart, and endoscopy if a fistula or an ulcer is suspected [21]. All these investigations also help to exclude other possible causes of dyspnea and chest pain like pericarditis, pneumonitis, aortic dissection, angina, myocardial infarction, and pulmonary embolism. Definitive tests for underlying mucormycosis include a histopathological examination of the tissue sample, culture, and PCR. Calcofluor white and methenamine silver stains can make a presumptive diagnosis of mucormycosis by demonstrating a characteristic broad, nonseptate hyphae with rightangle branching. Diagnosis can be confirmed by the identification of species in tissue cultures through histopathology. However, culture often yields no growth. Polymerase chain reaction (PCR) based techniques on histologic specimens can be more feasible. Furthermore, serum testing adds in differentiating mucormycosis from other fungal infections.

Small asymptomatic pneumopericardium needs close observation, as it usually resolves spontaneously. Symptomatic patients or those with a high risk of recurrence require immediate treatment with needle aspiration and pericardial tube placement for continuous drainage of the air $[5,15]$. Refractory cases require urgent thoracotomy with pericardiotomy along with high flow oxygen as it helps in the resorption of the air from the cavity $[15,22]$. Patients also require complete bed rest with head elevation, sedation, and analgesia. It is important to give low positive end-expiratory pressure (PEEP) in mechanically ventilated patients as high pressures can worsen the hypotension and pneumopericardium $[16,22]$. Untreated cases can lead to cardiac failure and circulatory collapse $[5,16]$. It can be accompanied by pneumothorax, pneumomediastinum, and subcutaneous emphysema which by itself carries a high mortality $[5,16]$.

\section{Conflicts of Interest}

The authors declare that they have no conflicts of interest.

\section{References}

[1] C. A. Kauffman and A. N. Malani, "Zygomycosis: an emerging fungal infection with new options for management," Current Infectious Disease Reports, vol. 9, no. 6, pp. 435-440, 2007.
[2] S. P. Hammond, R. Bialek, D. A. Milner, E. M. Petschnigg, L. R. Baden, and F. M. Marty, "Molecular methods to improve diagnosis and identification of mucormycosis," Journal of Clinical Microbiology, vol. 49, no. 6, pp. 2151-2153, 2011.

[3] E. J. Goldstein, B. Spellberg, T. J. Walsh, D. P. Kontoyiannis, J. Edwards Jr., and A. S. Ibrahim, "Recent advances in the management of mucormycosis: from bench to bedside," Clinical Infectious Diseases, vol. 48, no. 12, pp. 1743-1751, 2009.

[4] G. R. Gale and A. M. Welch, "Studies of opportunistic fungi: I. inhibition of rhizopus oryzae by human serum," The American Journal of the Medical Sciences, vol. 241, no. 5, pp. 604-612, 1961.

[5] R. G. Cummings, R. L. Wesly, D. H. Adams, and J. E. Lowe, "Pneumopericardium resulting in cardiac tamponade," The Annals of Thoracic Surgery, vol. 37, no. 6, pp. 511-518, 1984.

[6] A. E. Rosenbaum, H. I. Schweppe Jr., and E. R. Rabin, "Constrictive pericarditis, pneumopericardium and aortic aneurysm due to histoplasma capsulatum," The New England Journal of Medicine, vol. 270, no. 18, pp. 935-938, 1964.

[7] D. Xie, X. You, and G. Jiang, "Pneumopericardium due to Aspergillus empyema," Asian Cardiovascular and Thoracic Annals, vol. 23, no. 3, p. 346, 2015.

[8] A. van Ede, B. E. de Pauw, J. F. G. M. Meis, R. A. C. Koot, and F. M. J. Heystraten, "Pneumopericardium complicating invasive pulmonary aspergillosis: case report and review," Infection, vol. 22, no. 2, pp. 102-105, 1994.

[9] N. L. Muller, R. R. Miller, D. N. Ostrow, B. Nelems, and L. M. Vickars, "Tension pneumopericardium: an unusual manifestation of invasive pulmonary aspergillosis," American Journal of Roentgenology, vol. 148, no. 4, pp. 678-680, 1987.

[10] C. M. Owens, T. R. Graham, A. J. Wood, and A. C. Newland, "Bronchopericardial fistula and pneumopericardium complicating invasive pulmonary aspergillosis," Clinical \& Laboratory Haematology, vol. 12, no. 3, pp. 351-354, 1990.

[11] M. Yilmaz, A. E. Demirel, A. Mert et al., "Pneumopericardium due to invasive pulmonary aspergillosis," Journal of Infection and Chemotherapy, vol. 13, no. 5, pp. 341-342, 2007.

[12] A. Serrano-Gonzalez, J. M. Merino-Arribas, M. J. Ruiz-Lopez, and J. Casado-Flores, "Invasive pulmonary aspergillosis with pneumopericardium and pneumothorax," Pediatric Radiology, vol. 22, no. 8, pp. 601-602, 1992.

[13] R. Bhindi and D. M. Rees, "Pneumopericardium masquerading as an acute myocardial infarction," International Journal of Cardiology, vol. 114, no. 3, pp. E83-E84, 2007.

[14] J. Li, A. Omo, T. Chen, Z. Zheng, and T. Pan, "Tension pneumopericardium caused by pericarditis," Annals of Thoracic Surgery, vol. 83, no. 1, p. 321, 2007.

[15] P. J. Capizzi, M. Martin, and M. P. Bannon, "Tension pneumopericardium following blunt injury," Journal of TraumaInjury, Infection and Critical Care, vol. 39, no. 4, pp. 775-780, 1995.

[16] R. W. Emery, J. Foker, and T. R. Thompson, "Neonatal pneumopericardium: a surgical emergency," Annals of Thoracic Surgery, vol. 37, no. 2, pp. 128-132, 1984.

[17] M. J. Ivey and B. H. Gross, "Back pain and fever in an elderly patient," Chest, vol. 103, no. 6, pp. 1851-1853, 1993.

[18] D. Katzir, E. Klinovsky, V. Kent, A. Shucri, and Y. Gilboa, "Spontaneous pneumopericardium: case report and review of the literature," Cardiology, vol. 76, no. 4, pp. 305-308, 1989.

[19] W. F. Van Gelderen, "Stab wounds of the heart: two new signs of pneumopericardium," British Journal of Radiology, vol. 66, no. 789, pp. 794-796, 1993. 
[20] I. V. I. Costa, B. Soto, L. Dethelm, and P. Zarco, "Air pericardial tamponade," The American Journal of Cardiology, vol. 60, no. 16, pp. 1421-1422, 1987.

[21] É. Breatnach and S. Y. Han, "Pneumopericardium occurring as a complication of achalasia," Chest, vol. 90, no. 2, pp. 292-293, 1986.

[22] R. E. Behrman, J. J. Pomerance, M. H. Weller, C. J. Richardson, J. A. Soule, and A. Cato, "Pneumopericardium complicating respiratory distress syndrome: role of conservative management," The Journal of Pediatrics, vol. 84, no. 6, pp. 883-886, 1974. 


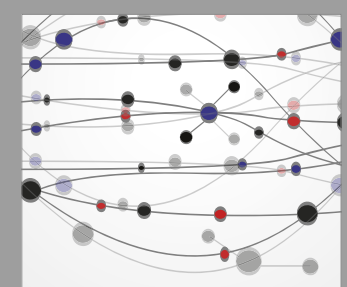

The Scientific World Journal
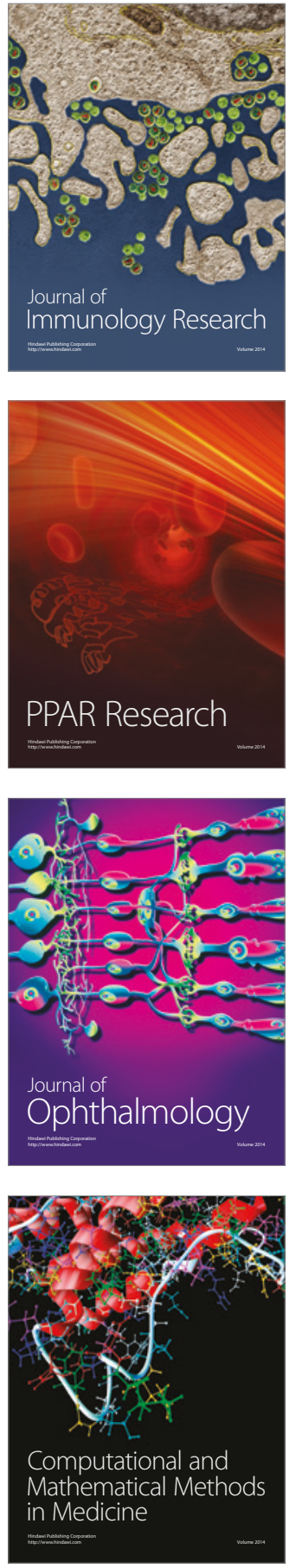

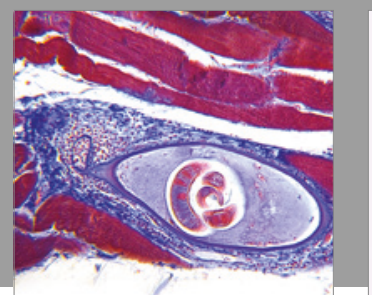

Gastroenterology Research and Practice
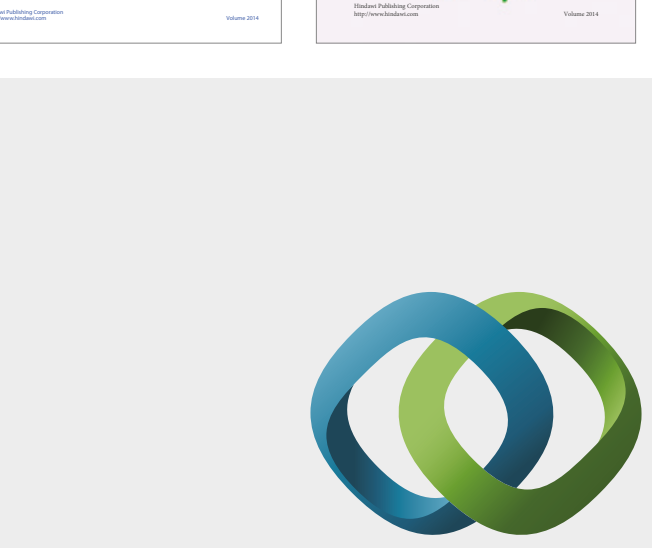

\section{Hindawi}

Submit your manuscripts at

https://www.hindawi.com
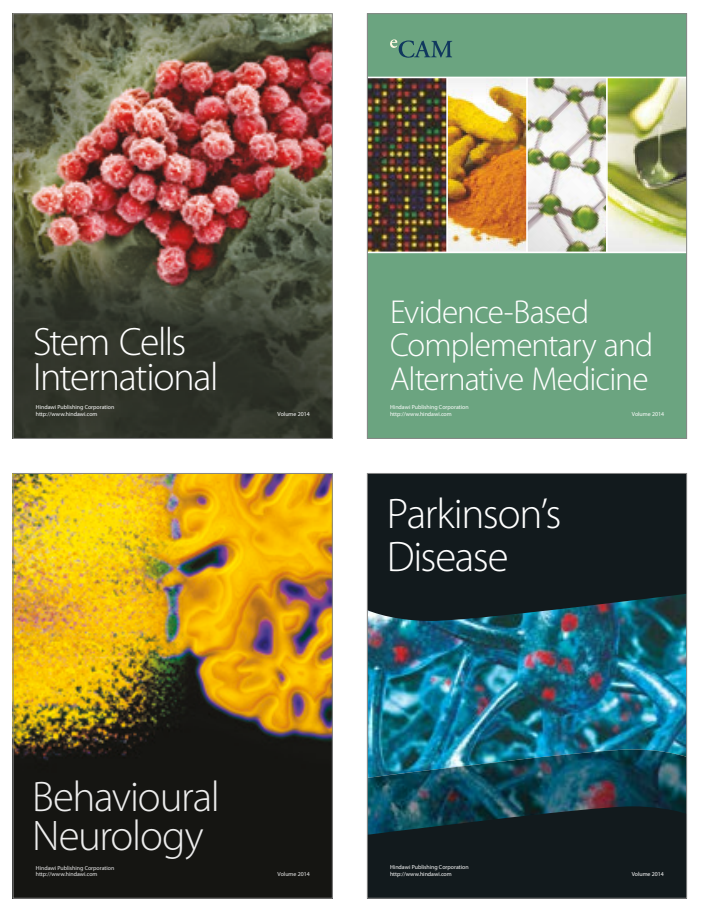
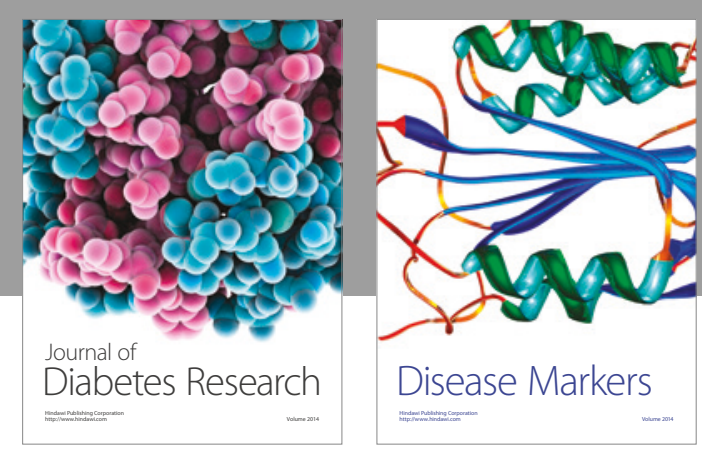

Disease Markers
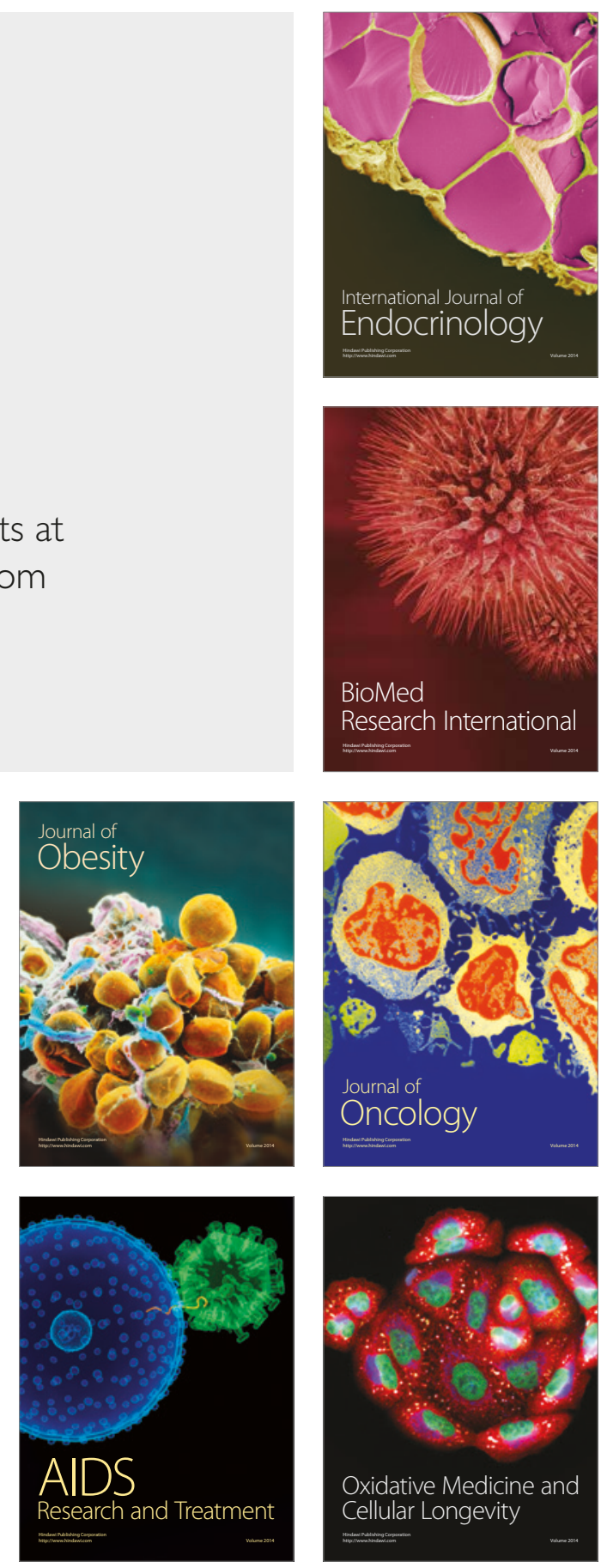